\title{
PERSPEKTIF SEGMENTASI DEMOGRAFI DAN PSIKOGRAFI PADA DAYA BIDIK PASAR PRODUK MEDIA DI DKI JAKARTA
}

\author{
Oleh: \\ Boyke Hatman \\ Program Studi Manajemen, \\ Sekolah Tinggi Ilmu Ekonomi Pengembangan Bisnis dan Manajemen \\ E-mail: \\ boyke.ht@gmail.com
}

\begin{abstract}
ABSTRAK
Segmentasi pasar merupakan dasar untuk mengetahui bahwa setiap pasar terdiri dari segmen yang berbeda. Di setiap segmen yang ditargetkan ada pembeli yang memiliki kebutuhan yang tidak sama, pola pembelian yang variatif dan tanggapan yang berbeda terhadap berbagai macam model penawaran. Untuk memenuhi keinginan setiap konsumen didapatkan berbagai perbedaan, meski tidak bisa dipenuhi dengan sempurna. Karena tidak ada yang bisa dengan cepat dan mudah untuk membangkitkan pasar sehingga memuaskan konsumen. Setiap segmen pasar mencerminkan peluang yang berbeda. Akan lebih baik jika dapat ditemukan model baru untuk menentukan segmentasi pasar. Masalah yang diteliti adalah apakah rendahnya jumlah pemasaran produk disebabkan oleh penempatan segmentasi yang tidak tepat? Dan apakah segmentasi dengan variabel demografi dan psikografi yang ditangani, sesuai dengan target pasar yang dibuat ? Pasar yang ditargetkan untuk pemasaran dalam segmentasi psikografis menurut nilai dan gaya hidup adalah masyarakat yang merupakan konsumen media dengan karakter optimis, memiliki sikap, memiliki keinginan untuk membuka peluang bisnis dan membutuhkan informasi yang berkaitan dengan ekonomi dan bisnis. Dalam penelitian ini ditemukan bahwa hubungan yang signifikan antara pekerjaan dan pendidikan terakhir pada frekuensi yang diperoleh pada alfa 0,05 dimana nilai Chi-square $\mathrm{X}^{2}$ hitung 16.36 lebih besar dari nilai kritis 9.49 dengan derajat hubungan klasifikasi. Klasifikasi pekerjaan dan pendidikan terakhir dalam tabel kontigensi adalah tingkat hubungan, hubungan atau ketergantungan klasifikasi 0,3766. Ada hubungan yang signifikan antara usia pembaca dan latar belakang pendidikan terakhir pada frekuensi yang diperoleh pada alfa 0,05 dimana Chisquare $\mathrm{X}^{2}$ hitung 16,03 lebih besar dari nilai kritis 12,592 dengan koefisien kontijensi usia pembaca dengan latar belakang pendidikan terakhir sebesar 0,37329 .
\end{abstract}

Kata Kunci: Segmentasi, Demografi, Psikografi. 


\section{A. PENDAHULUAN}

Informasi pada saat ini merupakan komoditas primer yang dibutuhkan orang, seiring dengan meningkatnya teknologi komunikasi. Sehingga lazim dikatakan peradapan masyarakat informasi. Telah menjadi pendapat umum siapa pengasa informasi dialah penguasa masa depan, sumber kekuatan baru bukanlah uang segelintir orang melainkan informasi ditangan banyak orang.

Berita merupakan sajian utama sebahagian besar media masa disamping opini dan pendapat. Dimana berita merupakan laporan tentang suatu kegiatan yang menarik perhatian khalayak pembaca tersaji dengan cepat dari suatu peristiwa yang aktual, penting, dan menarik bagi sebagian besar pembaca, serta menyakut kepentingan mereka.

Berita utama yang layak dipublikasikan oleh media cetak disampaikan dengan cepat, yakni aktual dan ketepatan waktu. Unsur ini terkandung makna harfiah berita yakni sesuatu yang baru tulisan jurnalistik, tulisan yang memberikan pemahaman pada pembaca atau tentang informasi yang tidak diketahui sebelumnya. Berita yang nyata, faktual yakni informasi tentang sebuah fakta, bukan fiksi atau karangan. Fakta dalam dunia jurnalistik terdiri atas kejadian nyata, pendapat dan pernyataan sumber berita, jadi sebuah berita merupakan informasi tentang sesuatu yang sesuai dengan kenyataan sebenarnya atau laporan mengenai fakta sebagai mana adanya. Pentingnya berita karena menyangkut orang banyak seperti berita berpengaruh pada kehidupan masyarat secara luas. Penyampaian yang menarik dari berita mengundang orang untuk membaca berita yang ditulis, disinilah diperlukannya kemampuan untuk membedakan mana fakta yang sebenarnya mempunyai nilai berita dengan yang tidak memiliki nilai berita.

Dengan data yang valid dan kongkrit yaitu data dan informasi yang benar benar riel dan jelas kita dapat melakukan penilaian dan menganalisis bagaimana kekuatan pasar yang ada dan seharusnya dihadapi, memperkuat pangsa pasar, meraih calon pasar yang kemungkinan dapat diraih oleh faktor kemampuan yang dimiliki oleh perusahaan ataupuin yang dapat diraih oleh faktor kemampuan yang dimiliki oleh perusahaan ataupun yang dapat diraih oleh faktor kemampuan yang dimiliki oleh perusahaan, yang dapat diraih dengan menggunakan strategi dan taktik maksimal sesesuai dengan pasar media yang dihadapi saat ini dan kemungkinan kondisi pasar yang akan datang. Dengan mengkaji dan menganalisis segmen pasar media maka secara pasti dapat dinilai proses kerja perusahaan dan distribusi dari output yang dihasilkan oleh perusahaan media ekonomi. Pengambilan keputusan yang tepat terhadap pasar sangat diharapkan oleh produsen produk maupun jasa, bila hal ini mengalami permasalahan maka alternatif yang muncul dapat dengan sendirinya dipecahkan atau setidaknya proses pemecahan permasalahan tidak memakan waktu yang berlebihan.

\section{B. KAJIAN PUSTAKA}

Pemasaran merupakan salah satu kegiatan pokok yang dilakukan pengusaha dalam mempertahankan kelangsungan hidup perusahaan, mendapatkan laba dan mengembangkan perusahaan. Pada Asosiasi Pemasaran Amerika atau American Marketing Association mendefinisikan pemasaran sebagai (Kasali R. , 2011), 
Adanya tahap - tahap yang dirumuskan, hal ini menunjukan pemasaran bukanlah kegiatan penekanan pada penawaran, tetapi merumuskan dari awal pada konsepsi seluruh bagian bersana - sama merumuskan produk dan memasarkannya.

Melibatkan produk, harga, promosi dan distribusi yang merupakan variabel dalam pemasaran disebut bauran pemasaran (marketing mix) yang merupakan alat pemasaran yang dapat dikendalikan oleh pemasar. Dari pemasaran dibutuhkan tujuan pasar yang sesuai dengan produk maupun jasa yang ditawarkan ataupun kondisi sebaliknya, untuk menuju pasar yang baik dan kuat dibutuhkan pembidikan pasar atau lebih dikenal sebagai segmentasi yang berarti suatu proses untuk membagi - bagi, mengelompokan kedalam kotak -kotak yang lebih homogen.

\section{Segmentasi Pasar}

Dalam pemasaran terhadap sasaran diperlukan langkah kunci yaitu segemtasi pasar, penetapan pasar sasaran, dan penentuan posisi produk. Segementasi pasar merupakan tindakan membagi pasar kedalam kelompokkelompok pembeli yang terpisah-pisah dengan kebutuhan dan tanggapan yang berbeda. Pemasar berusaha untuk membedakan variabel untuk melihat mana yang menunjukan peluang segmentasi terbaik. Bagi masing-masing segmen dikembangkan dengan gambaran segmen pelanggan. Keefektifan segmentasi bergantung pada pencapaian segmen yang dapat diukur, besar, dapat dijangkau, dapat dibedakan dan dapat diambil tindakan

Sasaran segmen pasar terbaik. Penjual pertama-tama harus mengevaluasi potensi masing - masing segmen dimana merupakan fungsi segmen ukuran dan pertumbuhan, segemn daya tarik structural, serta tujuan dan sumber daya. Dilanjutkan penjual memutuskan berapa banyak segmen yang dilayani. Dalam memilih segmen sasaran harus dipertimbangkan hubungan timbale balik dan rencana penyerangn segmen yang potensial.

Segmen yang berbeda - beda. Dalam setiap segmen yang dibidik terdapat pembeli yang memiliki : a. Kebutuhan yang berbeda, b. pola pembelian yang berbeda. c. Tanggapan yang berbeda terhadap berbagai macam penawaran.

Guna memenuhi setiap keinginan setiap konsumennya walau tidak dapat dipenuhi dengan sempurna, sebab tidak satupun perusahan yang dapat mencapai pasar dengan memuaskan pembeli. Setiap segmen dari pasar itu mencerminkan kesempatan yang berbeda - beda. Sebelum perusahaan mampu menempatkan posisi pada segmen - segmen tersebut, harus dipelajari terlebih dahulu kesempatan yang ada. Perusahan akan lebih beruntung bila dapat menemukan cara baru dalam menetapkan segmentasi pasar. Pada pola untk mengidentifikasi segmen preferensi yang berbeda - beda dalam menarik sebahagian besar orang dengan preferensi terkelompok - kelompok, pasar dapat menunjukan kelompok kelompok preferensi yang terpisah - pisah, yang disebut segmen pasar alami.dalam pasar ini memiliki tiga pilihan. Ia dapat berada ditengah dengan harapan dapat menarik seluruh kelompok. Ia dapat berada dalam segmen pasar yang terbesar. Ia dapat mengembangkan beberapa merek, masing - masing merek ditepatkan pada segmen yang berbeda. 
Berbagai hal harus menjadi pertimbangan untuk melakukan segmentasi pasar yang sesuai pada pembidikan pasar media ekonomi ditemui ini sejalan dengan teori yang dikemukakan oleh (Swasta, Dharmmesta, \& Irawan, 2016), yaitu :

1. Measurement (tingkat informasi yang ada mengenal sifat - sifat pembeli dapat diukur )

2. Accessibility (perusahaan secara efektif memusatkan usaha pemasaranya pada segmen yang dipilih)

3. Substantiality (tingkat dimana segmen itu adalah luas dan cukup menguntungkan untuk melakukan kegiatan pemasaran sendiri)

4. Actionability (segmen pasar tersebut dapat dilayani oleh perusahaan sesuai dengan kemampuannya)

Karena pasar sifatnya sangat beragam, maka sulit bagi produsen untuk melayaninya. Oleh kareannya pemasaran harus memilih segmen - segmen yang paling menguntungkan dan meninggalkan bagian pasar yang lainnya. Menurut Michael Porter diperlukan adanya segmentasi industri yaitu (Porter, 1985) "Pemilihan Industri menjadi sejumlah segmen yang diperlukan untuk menyumbang pada strategi bersaing. Segmentasi pasar biasanya lebih menekankan pada aktivitas pemasaran saja didalam rantai nilai.

Penetapan pasar sasaran memerlukan tiga langkah yaitu (Porter, 1985), sbb :

1. Segmentasi pasar, tindakan mengidentifikasikan dan membentuk kelompok pembeli yang terpisah - pisah mungkin membuntuhkan produk dan bauran pemasaran yang tersendiri.

2. Penetapan pasar sasaran, tindakan memiliki satu atau lebih segmen pasar untuk dimasuki.

3. Penetapan posisi pasar, tindakan membangun dan mengkomunikasikan manfaat fungsi istimewa dari produk di dalam pasar.

Segmentasi pasar merupakan suatu konsep yang sangat penting dalam kegiatan bisnis digunakan untuk memilih pasar sasaran, mencari peluang, mengerogoti segmen pemimpin pasar, merumuskan pesan pesan komunikasi, melayani lebih baik, menganalisis perilaku konsumen, mendisain produk. Salah satu metode yang digunakan untuk memilih pasar adalah segmentasi demografi atau sosioekonomi (Hiam \& Schewe, 2011). Variabel demografi meliputi usia, jenis kelamin, jumlah anggota keluarga, status perkawinan, suku bangsa, agama, tempat tinggal siklus hidup keluarga (Kotler \& Amstrong, 2012)

Pada penelitian pasar cenderung untuk melakukan pendekatan gaya hidup mengklasifikasikan konsumen berdasarkan variabel - variabel aktivitas, minat dan padangan - pandangan. Joseph Plummer mengatakan bahwa (Plummer, 1974) segmentasi gaya hidup mengukur aktivitas - aktivitas manusia dalam hal bagaimana mereka menghabiskan waktunya, minat mereka apa yang dianggap penting sekitarnya, pandangan - pandangannya baik terhadap diri sendiri maupun orang lain, karakter - karakter dasar seperti tahap yang mereka lalui dalam kehidupan, penghasilan, pendidikan, dan dimana mereka tinggal. 
Jika analisis demografis diabaikan, tidak mustahil produk tersebut akan mengalami kesulitan di pasaran. Perubahan itu dapat mengubah prioritas kebutuhan konsumen. Konsumen akan mengalami banyak hal baru dan membutuhkan pemecahan baru. Mereka membutuhkan produk yang lebih berkualitas, lebih ringkas, lebih praktis dan lainnya.

\section{Demografi}

Variabel demografi meliputi usia,jenis kelamin, jumlah anggota keluarga, status perkawinan, siklus hidup keluarga, suku kebangsaan, agama, tempat tinggal (Kotler \& Amstrong, 2012). Karakteristik dari sosio ekonomi yang meliputi penghasilan dan pendidikan (Hiam \& Schewe, 2011)

1. Usia, dengan mengelompokan usia menurut tingkat pendidikan, per sepuluh tahunan atau pengelompokan umur.

2. Jenis kelamin, tidak semua produk dapat dibedakan menurut kelompok segmen ini

3. Siklus hidup keluarga, disini konsumen dibagi - bagi menurut tahapan yang dapat dicapai seseorang dalam daur hidup keluarganya.

4. Pekerjaan, konsumen yang memiliki pekerjaan mengkonsumsi barang yang berbeda dengan pekerjaan lainnya.

5. Pendidikan, pasar dapat pula mengelompokan tingkat pendidikan yang dicapai konsumen. Pendidikan menentukan pendapatan dan kelas sosial seseorang, tingkat intelektualitas akan menentukan pilihan barang barang, jasa dan merek.

6. Pendapatan, dibedakan dengan berpenghasilan tinggi, menengah, bawah. Yang berpendapatan menengah pun dapat dibedakan menengah atas atau menengah bawah. Sedangkan kelas bawah dapat dibedakan kelas bawah bawah dan bawah atas.

7. Agama, segmentasi cara ini sangat sensitif dan memerlukan keseriusan dalam menjalin hubungan dengan konsumennya.

8. Suku dan kebangsaaan, konsumennya sepanjang suku - suku tersebut memiliki perbedaan yang mencolok dalam kebiasaan dan kebutuhan.

9. Jumlah atau ukuran keluarga, segmentasi ini dapatr dilakukan dengan membeda - bedakan pasar menurut besarnya anggota keluarga.

\section{Psikografi}

Psikografi adalah segmentasi berdasarkan gaya hidup, kelas sosial dan kepribadian manusia (Kotler \& Amstrong, 2012). Sedangkan gaya hidup mencerminkan bagaimana seseorang menghabiskan waktu dan uangnya yang dinyatakan dalam aktivitas - aktivitas, minat dan opini - opininya (Kasali R. , 2011) Dengan dasar sifat -sifat kepribadian, tingkat sosial ekonomi, sikap dan motivasi hal ini mempengaruhi pembelian seseorang terhasap suatu produk. Seseorang membeli produk yang berbeda dengan yang dibeli oleh orang lain bergantung pada tingkat kepuasan dan citra diri. Citra diri pada hakekatnya adlah suatu kombinasi yang komplek antara sikap terhadap diri sendiri dan hal - hal yang mencerminkan peranan yang dibawa oleh seseorang dalam masyarakat 
lingkungannya. Bentuk - bentuk produk dapat mencerminkan ego seseorang daripada produk - produk yang tingkat keterlibatan pembeliannya rendah.

Pendekatan yang dapat dilakukan dalam menganalisis variabel yang ada dalam kajian psikografi, seperti :

1. Konsumen dibeda - bedakan bedasarkan sifat - sifat kepribadian, tingkat sosial - ekonomi, sikap dan motivasi.

2. Konsumsi mencerminkan pandangan seseorang terhadap dirinya sendiri atau citra diri.

3. Mempertajam segmentasi demografi.

4. Gaya hidup dan kepribadian biasanya tercermin melalui riset - riset konsumen dengan menekankan pada tiga aspek (aktivitas, minat dan opini)

Di Indonesia sendiri dapat ditemukan 8 (delapan) segmen psikografi, sebagai berikut :

1. The affluent adalah pekrja keras, memiliki rasa percaya diri yang kuat, menyukai inovasi, proaktif, dan berani mengambil resiko, terbuka terhadap hal - hal yang baru dan mampu mempengaruhi orang lain.

2. The achievers, memiliki keterampilan memimpin, memiliki kecenderungan tidak suka diperhatikan orang lain, mengkonsumsi barang fungsional, pengambilan keputusan berdasarkan rasionaltas, tidak terlalu mudah menerima gagasan baru.

3. The anxious, segmen ini mempunyai sikap sebagai pengikut tetapi ambisius, memiliki percaya diri yang kuat dalam pengambilan keputusan dan senang menunjukan prestasinya, tetapi tidak memiliki keberanian, mudah dibujuk dengan hal - hal yang rasional.

4. The loner, segmen ini terdiri dari mereka yang senang menyendiri dan kurang berani tampil. Mereka cenderung individualistik dan kurang tertarik untuk berafiliasi dengan teman, tetangga atau orang sekitarnya.

5. Socialite, adalah segmen yang senang bergaul, bersosialisasi dengan orang lain. Tetapi mereka pengambil resiko yang beran berani bertindak meski kadar rasionalnya kurang kuat. Segmen ini memiliki kecenderungan untuk menguasai orang lain dan sedang menonjol.

6. The pusher, merupakan segmen yang terdiri dari orang -orang yang tidak ingin diperhatikan tetapi ingin mendominasi segala sesuatu tanpa arah yang jelas. Mereka tidak memeiliki obyektivitas yang jelas untuk meraih sesuatu tetapi senang mengontrol orang lain. Mereka tidak mudah menerima hal - hal yang baru.

7. The attention seekers, orang ini cenderung ingin menarik perhatian, mereka senang membeli sesuatu yang baru, impulsif dan tidak rasional memiliki kecenderungan mudah dibujuk secara emosional dan bersifat pengikut.

8. Pleasure, suatu segmen yang ingin meraih sesuatu tanpa kerja terlalu keras. Mereka cenderung individualistis. Kurang senang bersosialisasi, tetapi tekun mengikuti trend, mudah digoyangkan dan tidak menghendaki terjadinya perubahan. 
Dalam mengidentifikasi segmen utama pada suatu pasar diperlukan pendekatan dengan mengunakan 3 (tiga) tahap, yaitu :

1. Tahap survey

Pada tahap ini peneliti menyelenggarakan wawancara untuk mencari penjelasan dan memusatkan perhatian pada kelompok untuk memperoleh pandangan terhadap motivasi konsumen, sikap dan perilaku.

2. Tahap analisis

Tahapan ini peneliti mengunakan analisis faktor pada data untuk membuang variabel yang berkorelasi tinggi. Kemudian peneliti menggunakan analisis kelompok untuk menghasilkan penetapan jumlah segmen maksimum

3. Tahap pembentukan

Masing - masing kelompok dibentuk dengan persyaratan perbedaan sikap , perilaku, demografi, psikografi dan kebiasan konsumsi media mereka. Masing - masing segmen dapat diberi nama berdasar sifat - sifat dominan yang berbeda

\section{METODE PENELITIAN}

\section{Analisis Kualitatif}

Dilakukan dengan menginterpretasikan data - data kualitatif sesuai dengan teori - teori yang relevan dengan pemasaran dan realita yang terdapat dilapangan pada pasar industri media cetak ekonomi dan melihat kekuatan, kelemahan, ancaman serta peluang perusahaan untuk mengevaluasi kebijakan yang ditetapkan oleh perusahaan.

\section{Analisis Kuantitatif}

Dengan data kasar yang pada umumnya langsung diperoleh dari hasil pengukuran atau observasi. Pada data yang diperoleh dari hasil pengukuran atau observasi. Pada data yang diperoleh yang masih merupakan catatan ataupun data kasar maka dibuat sebuah distribusi frekuensi untuk pengukuran - pengukuran dengan pengelompokan yang sistematis, dengan itu kita dapat memperoleh gambaran yang jelas dan cepat mengenai suatu peristiwa dari urutan yang memuat puluhan angka.

a. Pembuatan distribusi frekuensi ini dengan membagi 3 (tiga) tahapan :

1. Menentukan jumlah kelas guna memasukan angka

2. Memasukan angka - angka kedalam kelas - kelas yang sesuai serta kemudian menghitung frekuensinya

3. Membuat tabel distribusi frekuensi.

b. Pengukuran nilai sentral dari data yang telah dikelompokkan

Avarage atau rata - rata dapat merupakan nilai yang cukup representatif rata rata tersebut dapat dianggap sebagai nilai sentral dan dapat digunakan sebagai pengukur lokasi sebuah distribusi normal. Cara menghitung rata - arata hitung dari data yang telah dikelompokan. 


$$
\begin{aligned}
X & =\frac{\mathrm{m}_{1} \mathrm{f}_{1}+\mathrm{m}_{2} \mathrm{f}_{3}+\ldots+\mathrm{m}_{\mathrm{k}} \mathrm{f}_{\mathrm{k}}}{\mathrm{f}_{1}+\mathrm{f}_{3}+\ldots+\mathrm{f}_{\mathrm{k}}} \\
& =\underline{\mathrm{n}}_{\mathrm{n}}^{\mathrm{k}} \square \square \mathrm{m}_{\mathrm{i}} \mathrm{f}_{\mathrm{i}}
\end{aligned}
$$

dimana :

$\mathrm{n}=$ jumlah observasi $=\square \square \mathrm{f}_{\mathrm{i}}$

$\mathrm{m}_{\mathrm{i}}=$ titik tengah interval kelas

$\mathrm{f}_{\mathrm{i}}=$ frekuensi kelas

$\mathrm{k} \quad=$ jumlah kelas

c. Menghitung median dari data yang telah dikelompokan

Perhitungan median dapat dilakukan secara langsung dengan menggunakan distribusi frekuensi kumulatif.

$$
\mathrm{M}_{\mathrm{d}}=\mathrm{B}+\frac{(\mathrm{n} / 2)-\mathrm{F}}{\mathrm{F}_{\mathrm{m}}-\mathrm{f}} \mathrm{i}
$$

Dimana :

$\mathrm{B}=$ tepi kelas bawah interval dimana median terdapat

$\mathrm{n}=$ jumlah nilai observasi

$\mathrm{F}=$ frekuensi kumulatif yang disesuaikan dengan $\mathrm{B}$

$\mathrm{i}=$ Besar interval kelas

d. Varian dan devasi standar dari data yang telah dikelompokan

Bila varians dan deviasi standar dihitung dari sebuah distribusi frekuensi, maka titik tengah masing - masing kelas umumnya dianggap sebagai nilai tunggal yang cukup representatif bagi semua nilai - nilai obeservasi $X_{i}$ yang dikelompokan kedalam kelas - kelas yang bersangkutan :

$$
\left.\mathrm{S}^{2}=\underset{\mathrm{n}}{\mathrm{n}=1} \underset{\mathrm{1}}{\mathrm{k}} \square \square \mathrm{m}_{\mathrm{i}}-\mathrm{x}\right)^{2} \mathrm{f}_{\mathrm{i}}
$$

Dimana :

$\mathrm{m}_{\mathrm{i}}=$ titik tengah tiap - tiap kelas

$\mathrm{f}_{\mathrm{i}}=$ jumlah frekuensi kelas

e. Chi-square (Good of Fit Test)

Uji ini adalah independensi, dimana variabel tidak dipengaruhi atau tidak ada hubungan dengan variabel lain, mengevaluasi kemungkinan bahwa hubungan 
nilai pengamatan disebabkan oleh chance (sampling error). Hipotesis nihil ditolak bila $\mathrm{X}^{2}$ yang dihitung dari sampel lebih besar dari nilai $\mathrm{X}^{2}$ dalam tabel berdasarkan taraf signifikan.

$$
\mathrm{F}_{\mathrm{e}}=\frac{(\square \square \mathrm{f} \text { kolom })(\square \square \mathrm{f} \text { baris })}{\text { Jumlah total }}
$$

Nilai Chi-square dihitung dengan :

$$
\mathrm{X}=\frac{\square \square\left(\mathrm{f}_{0}-\mathrm{f}_{\mathrm{e}}\right)^{2}}{\mathrm{f}_{\mathrm{e}}}
$$

menghitung derajat bebas (d.b): (baris - 1)(kolom-1)

Hitung nilai kritis uji good of fit test untuk derajat bebas (d.b):

Pada $\square \square=0,01 \quad 13,38$

Pada $\square \square=0,05 \quad 9,49$

Bila nilai Chi-square lebih kecil dari pada yang ditetapkan maka hal itu menyatakan tidak adanya hubungan yang signifikan satu dengan yang lainnya.

f. Koefisien Kontingensi C

Koefisien Kontingensi adalah uji korelasi antara dua variabel yang berskala data nominal. Fungsinya adalah untuk mengetahui asosiasi atau relasi antara dua perangkat atribut. Koefisien ini fungsinya sama dengan beberapa jenis koefisien korelasi lainnya. Kontingensi $\mathrm{C}$ adalah uji korelasi yang spesifik untuk data berskala nominal. Selain itu uji ini juga paling sering atau lazim digunakan dibandingkan uji koefisien korelasi data. Uji ini sangatlah erat kaitannya dengan uji chi-square. Sebab berdasarkan rumus uji koefisien ini, bahwa tidaklah mungkin koefisien ini dapat dihitung tanpa terlebih dahulu mengetahu nilai dari chi-square. Jadi, logikanya adalah hitung terlebih dahulu chi-square, baru kemudian hitung koefisien kontingensi.

$$
C=\sqrt{\frac{X^{2}}{N+X^{2}}}
$$

Rumus Kontingensi C

$$
X^{2}=\sum_{i=1}^{b} \sum_{j=1}^{k} \frac{\left(A_{i j}-H_{i j}\right)^{2}}{H_{i j}}
$$

\section{HASIL DAN PEMBAHASAN}

Dalam mencapai target pemasaran suatu produk pada dasarnya melihat konsep strategi pemasaran yang mendasarinya. 


\section{Hubungan Segmentasi Pasar Berdasarkan Demografi dan Psikografi}

Dari data yang didapat dapat dilhat mengenai profil dari pembaca. Pada profil pembaca didapat persentase dari jumlah frekuensi masing - masing kategori dalam segmentasi demografi yaitu pekerjaan. Dari hasil survei terdapat segmentasi yang dibidik ditemukan persentase angka kemampuan menjadi pangsa pasar dengan perbandingan menurut pekerjaan yaitu : pengusaha dengan persentase sebesar 39,19 persen dan pegawai dengan persentase 37,83 persen kedua jenis yang termasuk kedalam kategori pekerjaan dalam segmentasi demografi ini memiliki kekuatan untuk menjadi target pasar yang harus dikembangkan dan dipertahankan. Pada usia pembaca 30 - 49 tahun merupakan segmen pasar yang dibidik karena dari hasil temuan dilapangan antara usia tersebutlah yang memiliki keinginan lebih dibandingkan dengan usia antara 20 29 tahun dan usia lebih dari 50 tahun yang memiliki persentase menurut frekuensi yang ditemukan 22,4 persen dan 10,3 persen . Pada kategori menurut jenis kelamin laki - laki memiliki kekuatan lebih besar dengan persentase 89,5 persen dibandingkan wanita 10,5 persen . Pada temuan menurut kategori pendidikan terakhir dapat diketahui latar belakang akademis universitas merupakan pasar yang memiliki kemampuan terbesar dengan penyerapan yang lebih muda dibandingkan tamatan SMA atau Diploma dengan persentae pada pendidikan terakhir universitas sebesar 55,2 persen

\section{Hasil Pengolahan dan Data Survei Lapangan}

Dari angka persentase respon kepada pada responden yang dituju oleh penulis sesuai dengan targen segmen yang dibidik bahwa dari hasil perhitungan distribusi frekuensi, rata - rata hasil nilai konsumen yang dibidik, median distribusi dan menghitung rata - rata varian deviasi standar yaitu pegawai negeri sipil, pegawai swasta dan pengusaha didapat hasil bagi pegawai negeri sipil dengan rata - rata serangkaian data sebesar 14,6162 dengan standar deviasi sebesar 6,5169. Pada pegawai swasta dengan rata serangkaian data sebesar 29,7678 dengan standar deviasi sebesar 8,4664. Sedangkan pada segmen pengusaha didapat hasil perhitungan dengan rata - rata serangkaian data sebesar 14,6162 dengan standar deviasi sebesar 6,5169. Dari perhitungan dengn nilai tabel chi-square dapat dilihat jumlah $\mathrm{X}^{2}$ adalah 16,36 .. Nilai kritis $\mathrm{X}^{2} \quad 0,05$; derajat bebas $(3-1)(3-1)=9,488$. Uji ini menunjukan bahwa ada hubungan yang signifikan antara pekerjaan dan lulusan pada score kuesioner yang diberikan dengan alpa 0,05 dimana nilai $X^{2}$ hitung adalah 16,36 lebih besar dari nilai kritis 9,49. Jumlah $X^{2}$ adalah 16,03 dari tabel nilai chi-square. Nilai kritis 0,05 ; derajat bebas $(4-1)(3-1)=12,592$.

Untuk melihat hubungan usia pembaca dengan latar belakang pendidikan dapat dibuktikan bahwa ada hubungan yang signifikan pada alpha 0,05 dimana nilai $X^{2}$ hitung adalah 16,03 lebih besar dari nilai kritis sebesar 12,592. Dengan menggunakan metode chi-square good of fit test yang dapat melakukan perhitungan secara multinominal yaitu eksperimen lebih dari dua dilakukan analisa kuantitatif untuk menentukan berhubungan atau tidaknya variabel dengan yang lainnya. 


\section{Kebijakan Segmentasi Pasar Yang Efektif}

Dari hasil penelitian ditemukan segmen pasar yang dapat dibidik untuk pemasaran yaitu kalangan pekerja yang memilki latar belakang pendidikan universitas yang menyukai dan membutuhkan informasi dari media ekonomi sebesar 52,2 persen. Penyajian informasi, analisis dan peluang bisnis ke dalam isi merupakan kebutuhan mereka dan dari usia konsumen yang disurvei yaitu $20-59$ tahun keatas diperoleh bahwa usia 30 - 39 tahun sebesar 35,1 persen dan $40-49$ tahun sebesar 33,2 persen dari 100 persen usia 20 - 59 tahun, ini adalah segmen yang mampu untuk dibidik dalam pemasaran media. Pada segmen menurut pekerjaan pada pegawai negeri sipil sebesar 22,97 persen, pegawai swasta 37 persen dan pengusaha sebesar 39,19 persen dari frekuensi masing - masing segmen dengan tiga kategori pekerjaan dibagi penjumlahan frekuensi ke tiga pekerjaan tersebut dikalikan seratus persen.

\section{E. SIMPULAN}

Segmentasi pasar dari produk majalah ekonomi menurut kategori segmen demografi dan psikografi pada pengkajian segmentasi pasar kapasitas produk media ekonomi, memiliki pagsa pasar segmentasi demografi berpendidikan terakhir Universitas, pekerja, pengusaha dan pegawai swasta berusia 30 -46 tahun, berjenis kelamin laki - laki. Pasar yang dibidik untuk pemasaran pada segmentasi psikografi menurut vals (value and life style) adalah masyarakat konsumen media yang berjiwa optimis, memiliki pendirian, memiliki keinginan untuk membuka peluang usaha dan membutuhkan informasi yang berkaitang dengan ekonomi dan bisnis. Kalangan pekerja yang memiliki latar belakang pendidikan universitas merupakan pasar baik untuk dibidik karena menyukai dan membutuhkan informasi dari media ekonomi sebesar 55,2 persen, dengan latar belakang pendidikan SMA 26,7 persen dan yang memilki latar belang pendidikan akademi 18,1 persen. Informasi, analisis dan peluang bisnis kedalam isi merupakan kebutuhan bagi konsumen dengan usia konsumen 20 - 59 tahun keatas diperoleh hasil bahwa usia 30 - 39 tahun sebesar 35,1 persen, 40 - 49 Tahun sebesar 32,2 persen.

Pada jenis kelamin segmen yang dimilki memiliki kekuatan pasar adalah lelaki dengan persentas sebesar 89,5 persen dan wanita sebesar 10,5 persen. Pekerjaan dan jabatan yang diduduki oleh pemburu peluang usaha, pekerjaan yang karirnya sedang menanjak pada kategori pekerjaan menurut segmentasi demografi yaitu : pekerja sebagai pegawai negeri sipil sebesar 22,97 persen, pegawai swasta 37 persen dan pengusaha 39,19 persen.

Konsumen yang memiliki kebutuhan untuk mendapatkan informasi lebih mengenai ekonomi dan bisnis melalu media dapat dilihat bahawa pada pegawai negeri sipil sebesar 21,54 persen, pegawai swasta 36,92 persen dan pengusaha sebesar 40 persen menurut kategori pekerjaan

Ada hubungan yang signifikan antara pekerjaan dan pendidikan terakhir pada frekuensi yang didapat pada alpha 0,05 dimana nilai Chi-square $\mathrm{X}^{2} \cdot$ hitung 
16,36 lebih besar dari pada nilai kritis 9,49 dengan derajat hubungan dari klasifikasi - klasifikasi pekerjaan dan pendidikan terakhir dalam kontigensi sebesar derajat hubungan, asosiasi dari klasifikasi dalam kontigensi $\mathrm{C}=0.3766$.

Ada hubungan yang signifikan antara usia pembaca dengan latar belakang pendidikan terakhir pada frekuensi yang didapat pada alpha 0,05 dimana nilai Chi-square $\mathrm{X}^{2}$ hitung 16,03 lebih besar dari pada nilai kritis 12,592 dengan koefisien kontigensi $\mathrm{C}$ atau derajat hubungan dari klasifikasi - klasifikasi usia pembaca dengan latar belakang pendidikan terakhir dalam kontigensi $\mathrm{C}$ sebesar 0,37329 . 


\section{DAFTAR PUSTAKA}

Dauglas, L. (2016). Global Marketing. USA: Blackwell Publishing Inc.

Hiam, A., \& Schewe, C. D. (2011). The Portabel MBA in Marketing. USA: Massachusetts.

Joel, Y. 1. (1992). Marketing to Young Consumers: Segmentation Plus Life-Style. Amsterdam: The Nederland.

Kasali, R. (2009). Marketing in Crisis, Marketing Therapy, Menyerang Pasar dan Mangambil Manfaat dari Krisis Ekonomi. Jakarta: Gramedia Pustaka Utama.

Kasali, R. (2010). Myelin Mobilisasi Intangibles menjadi Kekuatan Perubahan. Jakarta: Gramedia Pustaka Utam.

Kasali, R. (2011). Membidik Pasar Indonesia. Jakarta: Gramedia Pustaka Utama.

Kasali, R. (2012). Cracking Values. Jakarta: Gramedia Pustaka Utama.

Keller, K. L., \& Kotler, P. (2016). Marketing Management Edition 15. USA: Pearson.

Kotler, P. (2004). Manajemen Pemasaran Edisi Milenium Satu. Jakarta: PT Indeks.

Kotler, P., \& Amstrong, G. (2012). Prinsip-Prinsip Pemasarn Edisi Ketiga Belas. Jakarta: Erlangga.

Normann, R., \& Ramirez, R. (2013). From Value Chain to Value Constellation: Designing Interactive Strategy. USA: HBR.

Plummer, J. (1974). The Concept and Application of Life Style Segmentation. USA: Journal Marketing.

Porter, E. M. (1985). Competitive Advantage, Creative and Sustaining Superior Performance. USA: MEP.

Swasta, B., Dharmmesta, \& Irawan. (2016). Manajemen Pemasaran Modern. Yogyakarta: Liberti. 